\title{
Groundwater Resource Appraisals of Bodinga and Environs, Sokoto Basin North Western Nigeria
}

\author{
${ }^{*}{ }^{1} \mathrm{H}$.Hamidu, ${ }^{2}$ M. L. Garba, ${ }^{2}$ Y.I. Abubakar, ${ }^{2}$ U. Muhammad, ${ }^{1 D}$. Mohammed \\ 1Department of Geology, Usmanu Danfodiyo University, Sokoto, Nigeria. \\ 2 Department of Geology, Ahmadu Bello University, Zaria, Nigeria. \\ [ ${ }^{\star}$ Corresponding author:E-mail:hassanhamidu@yahoo.com; :+2348137874473]
}

\begin{abstract}
The groundwater resources of semi-arid region of Bodinga town and its environs within the Sokoto basin of Northwestern Nigeria have been evaluated. Data obtained at site during pumping test sessions which lasted for a period of between 8-12 hours for a total of 67 boreholes in the area of study were used alongside Information gathered from the careful analysis of lithological logs of the drilled Boreholes. The Hydraulic conductivity for the Kalambaina, Wurno, and Taloka formations are $22.00 \times 10 \mathrm{~m} / \mathrm{s}, 8.00 \times 10^{-1} \mathrm{~m} / \mathrm{s}$, and $1.02 \times 10 \mathrm{~m} / \mathrm{s}$ and respectively with an average of $3.00 \times 10 \mathrm{~m} / \mathrm{s}$ for the area. The Transmissivity calculated for these formations are $167.54 \times 10 \mathrm{~m}^{2} / \mathrm{s}$, $3.02 \times 10 \mathrm{~m}^{2} / \mathrm{s}$ and $3.00 \times 10 \mathrm{~m}^{2} / \mathrm{s}$ respectively while the average total for the area is. $20.30 \times 10 \mathrm{~m}^{2} / \mathrm{s}$. Specific capacity for the Kalambaina is $140.00 \times 10 \mathrm{~m}^{2} / \mathrm{s} / \mathrm{m}$, for Wurno the value is $2.10 \times 10 \mathrm{~m}^{2} / \mathrm{s} / \mathrm{m}$ while Taloka formation have a value of $2.35 \times 10 \mathrm{~m}^{2} / \mathrm{s} / \mathrm{m}$ and the mean computed for this part of the basin is $16.30 \times 10 \mathrm{~m}^{2} / \mathrm{s} / \mathrm{m}$. Yield is between $0.23 \mathrm{l} / \mathrm{s}$ and $6.7 \mathrm{l} / \mathrm{s}$. The calculated properties show the area to be rich in groundwater resources mainly tapped from the coarse sandy and cavernous/jointed limestone layers. However the high drawdown values recorded in some of the boreholes is attributed to the presence of silt- clay materials which act as aquiclude. The high yielding boreholes are those with thicker and sandy aquifer material and less drawdown, however the area have high groundwater resource that is partly affected by the presence of silt and clay intercalations within the sandy Aquiferous units.
\end{abstract}

Keywords: Groundwater, Transmissivity, Coarse-sandy layer, Aquiclude, Semi-confined, Sokoto basin.

\section{INTRODUCTION}

Early work on the Sokoto basin concentrated on the geology of the area dated as far back as the 1800, this includes those of Jones (1948) and Parker (1964). Hydrogeological investigation on the basin was first carried out by Tattan (1930). Du preez and Barber(1965). The most comprehensive hydrogeological work on the basin is that of Anderson and Ogilbee (1973), the work described the general hydrogeology of the basin and mostly concentrated on the Artesian wells and deep wells in the basin. In their study of the Rima aquifer within the area of the present study (Bodinga) carried out by these researchers, a transmissivity of $65000 \mathrm{gpd}$ per feet was computed for a borehole drilled by geological survey of Nigeria and a drawdown of $0.9 \mathrm{~m}$ recorded in an observation well located $10.1 \mathrm{~m}$ away at a pumping rate of $5,140 \mathrm{gph}$ for 24 hours. Another GSN borehole at shuni town which tap the Rima in the area under study, (N.3511) has a yield of $5,290 \mathrm{gph}$ with a recorded drawdown of $7.3 \mathrm{~m}$. For borehole GSN.3512 located at Dange town, this tap water from the Gundumi formation the authors computed Transmissivity of $22,800 \mathrm{gal} /$ day/feet with hydraulic conductivity of $457 \mathrm{~g} / \mathrm{d} / \mathrm{f}^{2}$ and a yield of 1,570 gph. Hamidu et al (2015), recorded an average yield of $4.1 \mathrm{l} / \mathrm{s}$, transmissivity and specific capacity averages of $1.70 \times 10 \mathrm{~m}^{2} / \mathrm{s}$ and $1.40 \times 10 \mathrm{~m}^{2} / \mathrm{s} / \mathrm{m}$ respectively for the Gundumi formation of Talata Mafara town and its environs Other works that contributed to the study of the hydrogeology of the basin included that of Oteze(1976), JICA (1990), Umar (2000), Alagbe_(2004), Maduabuchi (2002), Adelena et al (2006) and Guillaume et al (2011).

This present work was aimed at carrying out an in depth study on the groundwater resource potentials of Bodinga area, the choice of this area is not far from the fact that the geology of the area consist of overlaps of the different geological formations of the basin outcropping to the surface in this part of Sokoto basin. The previous work of Anderson and Ogilbee (1973), studied the hydrogeology of the whole basin, this study concentrated on a portion of the basin to give a more detail and clear picture of the hydrogeology of the area by using more data and different method of analysis.

\section{Physical Setting, Climate and Hydrology}

The lullemeden basin in Nigeria is represented by semi consolidated rocks which outcrop to the surface as undulating plain broken at intervals by hills of clay which are Paleocene sediment (Sokoto group), while the last two overlies the Gwandu and other capped at the top with ferruginous ooliths, laterites or ferruginized sandstone. The first type of superficial deposit overlies 
the formations that outcrop to the surface in the basin, Kogbe (1979). The hilly topography nearly exceeds 46 $\mathrm{m}$ at the Dange scarp which is a steep-sided flat topped hill with a low escarpment, which is the highest relief future in the area. Generally, the more elevated surfaces are found on the iron stone cap hills. The average elevation of the land in this basin is between 250-400 metres above sea level.

Two climatic seasons exist in the basin, a short wet season lasting from the months of May to October with the rain initiated by the northward movement of the moist equatorial maritime air mass (ref.). The rain increases southward with an annual average of value of $670 \mathrm{~mm}$. The longer dry hamattan period lasting between October-April, is characterized by dry dustladen winds of the tropical continental mass. The coolest months are between December and January where temperature falls to $16{ }^{\circ} \mathrm{C}$ while the hottest month is April with the highest temperature of about 40 ${ }^{\circ} \mathrm{C}$, while the daily minimum is $24^{\circ} \mathrm{C}$. The annual mean temperature fluctuate between 21.5 and $34.9^{\circ} \mathrm{C}$.

Because of the low rainfall distribution in the area, the vegetation cover type is the Sudan savanna type (ref.). Mainly this is characterized by spars scrubs which are not up to $6 \mathrm{~m}$ tall. Large isolated trees are also common, characterized by fine-leafed and thorny structures. Broad leaf varieties do exist southward in the basin due to increase in rainfall.

The Rima and Sokoto rivers forms the main drainage system in the basin, these join each other at Dundaye area. The main source of the river is the crystalline rock located east of the basin. The river flow westward and southward cutting through the Rima and Sokoto groups as well as the Gwandu formation. The Rima, Gagare, Bunsuru, Kware, Zamfara, Gayan, and Gulbin Ka Rivers are the tributaries to the Sokoto River. The Sokoto river and its tributaries are perennial, this is made possible during the dry season from recharge receive through base flow, springs, and the parch water body of the Kalambaina Limestone formation, Anderson and Ogilbee (1973).

\section{Geology}

The area of study is located south of Sokoto town and falls within the Nigerian sector of the lullemeden basin and is between latitude $12^{\circ} 30^{\prime}$ and $13^{\circ} 00^{\prime}$ and longitude $5^{\circ} 00^{\prime}$ and $5^{\circ} 30^{\prime}$ with a total land area of 3,040 $\mathrm{km}^{2}$. From the bottom upward the geology of the area comprises the crystalline complex, below the ground this is encountered at a depth of more than $520 \mathrm{~m}$. Outcrops of the crystalline complex west of Sokoto and beyond the sedimentary rock limit exposes granite, gneisses, phyllite and quartzite as the rocks of the basement suit. The rocks of the crystalline complex are pre Cambrian in age. Above the basement complex unconformably lies the IIIo and Gundumi formations with thickness of $120 \mathrm{~m}$ and $320 \mathrm{~m}$ respectively, Kogbe (1979). They comprise of grits, clayey-sand and clay with its base mainly made up of conglomerate. The group is continental fluvio-lacustrine in origin with age of lower Cretaceous.

Overlying the continental Gundumi formation is the Maastrichtian Rima group, this was unconformably deposited and consist of three formations, a lower Taloka formation of sandstone and mudstone with maximum thickness of about $100 \mathrm{~m}$. Mainly this consist of white fine grained, friable sandstones and siltstone with a thin layer of intercalated mudstone and carbonaceous mudstone or shale. The Dukamaje formation overlies the Taloka; this is made up of shales with some limestone and mudstone with a maximum thickness of about 23 metres. The uppermost layer of the Rima group is the Wurno formation, with similar lithology to Taloka formation, the carbonaceous material present in the Wurno is responsible for its dark colour. The surface exposure of the Wurno is about 25 $\mathrm{m}$ thick. The Sokoto group overlies the Rima, it is marine in origin consisting of a lower shalley Dange formation which is an aquiclude with thickness of between $22 \mathrm{~m}$ to $45 \mathrm{~m}$. The Kalambaina is made up of clayey, chalky or nodular continental limestone and shale with thickness of about $20 \mathrm{~m}$. An upper most Gamba formation made up of $7 \mathrm{~m}$ of clay, calcareous clay and laminated shale overlies the Kalambaina. At the top of the Sokoto group is a layer of laterite and windblown sand, the Sokoto group is Palaeocene in age. The Gwandu formation is the youngest sequence and continental, consisting of massive clay-mudstone interbeded with coarse and medium grained sandstone with a thickness of over 75 metres. The age of this formation is Eocene - Tertiary, Figure 1. 


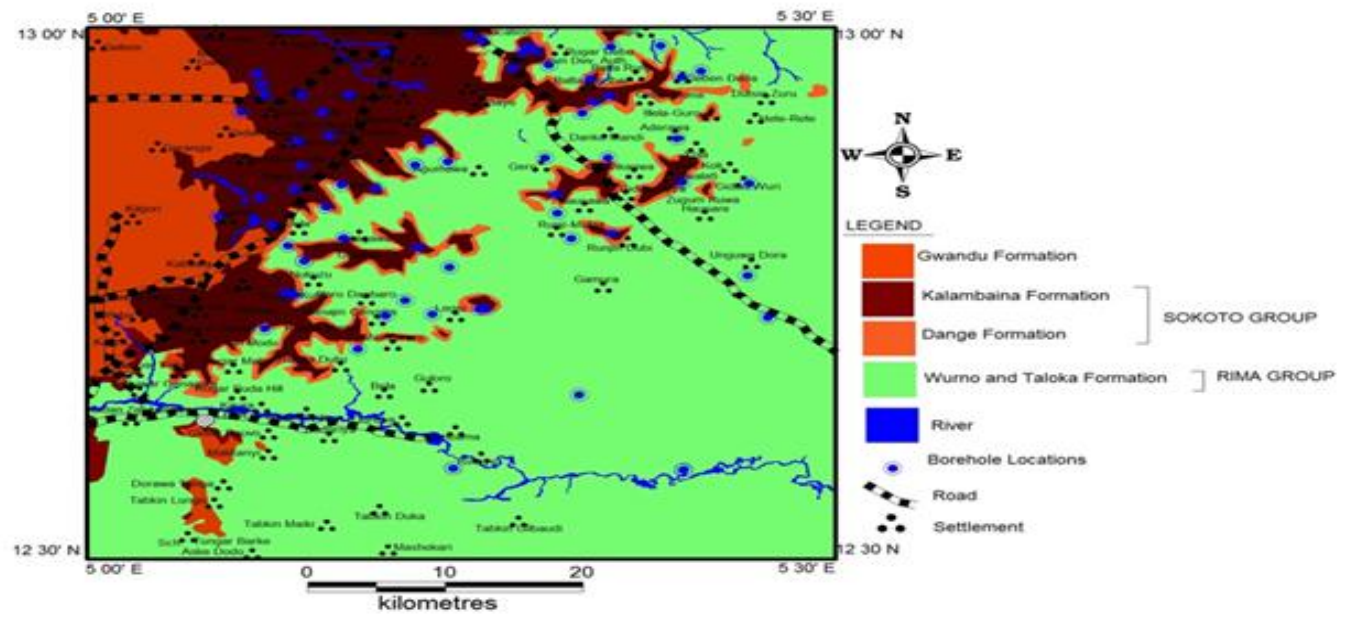

Figure 1: Subsurface Geology Map Of The Area Of Study Showing The Location Of Boreholes

sedimentary formations in the Sokoto basin. Data such

For the Rima group and Gwandu formation, the water producing layers are the coarser sandy zone which should be thick enough to give the desire higher yield. From table 1 It will be noticed that higher yield are obtained from boreholes that has low drawdown values, thicker water bearing zones, coarse and clay free layers. It was also observed that the lower the drawdown the thicker the aquifer, and the coarser the aquifer material, the more the water stored and transmitted from the aquifer in the borehole. Also the low drawdown shows that the rate of discharge in these boreholes nearly equals the recharge which shows also that the aquifers in such locations are porous and highly permeable especially the limestone aquifer of the Kalambaina formation due to the presence of solution cavities that serve as conduits for the free flow or transmission of water resulting from high permeability created by the secondary opening in the limestone.

Generally, in this area of study the water producing layers are the fine, medium, Coarse Sand and Cavernous Jointed limestone layers. From the

\section{MATERIALS AND METHOD}

The borehole data used for this study were obtained from the completion report of the drilled boreholes prepared by Wardrop engineering consultant to the Sokoto Agricultural and Rural Development Authority (S.A.R.D.A). The information covers the different as aquifer thickness, borehole depth, and material composition of the water producing units, were all deduced from the lithological borehole logs of the 67 boreholes drilled in the area of study. These data were analysed alongside the information gathered during the pumping test at site which include borehole yield, drawdown, static water level and pumping rate. The pumping test lasted for a period of between 8 to 12 hours depending on the time at which the individual borehole been pumped achieved equilibrium, with pumping rate ranging between 7 and $75 \mathrm{lpm}$ which depends on the yield of the pumping well and on the borehole response to water abstraction. The information on the yield and drawdown were substitute in the Logan (1964) empirical relation to compute the Transmissivity and Specific capacity. This is giving by

$\mathrm{T}=\mathrm{a} \times(\mathrm{Q} / \mathrm{s})$ where $\mathrm{T}=$ Transmissivity $\left(\mathrm{m}^{2} / \mathrm{s}\right)$

$\mathrm{a}=$ dimensional constant $=1.22$

$Q=$ yield of borehole $\quad=(1 / \mathrm{s})$

$S=$ Recorded maximum drawdown in the Pumpingwell.

The Hydraulic conductivity was computed using $\mathrm{K}=$ $T / b$ where:

$\mathrm{K}=$ Hydraulic conductivity $(\mathrm{m} / \mathrm{s})$

$b=$ Thickness of aquifer or screen length used. 
The Topographical map sheet of the area was used as a base map to produce the geological map with the borehole location plotted on it (figure 1).

\section{RESULTS}

The result of the study is presented in Table 1. The calculated hydraulic properties for the aquifer in the different formations within the area studied in this part of the basin are discussed below.

\section{Transmissivity}

The calculated transmissivity of Kalambaina formation ranges from $2.64 \times 10^{-1}$ and $817.40 \times 10 \mathrm{~m}^{2} / \mathrm{s}$ with an average of $170.00 \times 10 \mathrm{~m}^{2} / \mathrm{s}$, the Wurno formation has a transmissivity value that ranges between $1.77 \times 10^{-2}$ $\mathrm{m}^{2} / \mathrm{s}$ and $37.20 \times 10 \mathrm{~m}^{2} / \mathrm{s}$ with a mean value of $3.02 \times 10$ $\mathrm{m}^{2} / \mathrm{s}$. The Transmissivity value for the Taloka formation in the area is from $5.00 \times 10^{-2} \mathrm{~m}^{2} / \mathrm{s}$ to $5.50 \times 10$ $\mathrm{m}^{2} / \mathrm{s}$ with an average of $3.00 \times 10 \mathrm{~m}^{2} / \mathrm{s}$. Only two boreholes drilled in the area terminated within the Gwandu formation and these have a Transmissivity of $2.33 \times 10^{-1} \mathrm{~m}^{2} / \mathrm{s}$ and $9.62 \times 10 \mathrm{~m}^{2} / \mathrm{s}$ with a mean of $4.92 \times 10 \mathrm{~m}^{2} / \mathrm{s}$. The total average value for the area of study is $20.30 \times 10 \mathrm{~m}^{2} / \mathrm{s}$

\section{Specific Capacity}

The specific capacity of the Kalambaina is between $2.17 \times 10^{-1} \mathrm{~m}^{2} / \mathrm{s} / \mathrm{m}$ and $670.00 \times 10 \mathrm{~m}^{2} / \mathrm{s} / \mathrm{m}$ with a mean value of $140.00 \times 10 \mathrm{~m}^{2} / \mathrm{s} / \mathrm{m}$. Wurno formation has values ranging from $1.45 \times 10^{-2} \mathrm{~m}^{2} / \mathrm{s} / \mathrm{m}$ to $30.50 \times 10$ $\mathrm{m}^{2} / \mathrm{s} / \mathrm{m}$ with a calculated average of $2.10 \times 10 \mathrm{~m}^{2} / \mathrm{s} / \mathrm{m}$. For Taloka formation, the specific capacity values ranges between $4.10 \times 10^{-2} \mathrm{~m}^{2} / \mathrm{s} / \mathrm{m}$ and $4.50 \times 10 \mathrm{~m}^{2} / \mathrm{s} / \mathrm{m}$ while computed average is $2.35 \times 10 \mathrm{~m}^{2} / \mathrm{s} / \mathrm{m}$. The two boreholes that intercepted the Gwandu formation in the area have specific capacity values of $2.00 \times 10^{-1} \mathrm{~m}^{2} / \mathrm{s} / \mathrm{m}$. and $8.00 \times 10 \mathrm{~m}^{2} / \mathrm{s} / \mathrm{m}$ with average of $4.10 \times 10 \mathrm{~m}^{2} / \mathrm{s} / \mathrm{m}$. The average for the area of study is $16.30 \times 10 \mathrm{~m}^{2} / \mathrm{s} / \mathrm{m}$.

\section{Hydraulic Conductivity}

The Kalambaina formation has hydraulic conductivity range of between $5.10 \times 10^{-2} \mathrm{~m} / \mathrm{s}$ and $91.00 \times 10 \mathrm{~m} / \mathrm{s}$ with a mean of $22.00 \times 10 \mathrm{~m} / \mathrm{s}$. For Wurno formation the values of hydraulic conductivity are from $7.07 \times 10^{-3} \mathrm{~m} / \mathrm{s}$ to $14.90 \times 10 \mathrm{~m} / \mathrm{s}$ and with a mean of $8.00 \times 10^{-1} \mathrm{~m} / \mathrm{s}$, while Taloka have a range of between $1.41 \times 10^{-2} \mathrm{~m} / \mathrm{s}$ and $2.20 \times 10 \mathrm{~m} / \mathrm{s}$ with average of $1.02 \times 10 \mathrm{~m} / \mathrm{s} / \mathrm{m}$. The only two boreholes that tap the Gwandu formation have a range of between of $9.33 \times 10^{-2} \mathrm{~m}^{2} / \mathrm{s}$ and of $3.85 \times 10 \mathrm{~m} / \mathrm{s}$ while the average for this formation is
$1.96 \times 10 \mathrm{~m} / \mathrm{s}$. The mean hydraulic conductivity value for the area is of $3.00 \times 10 \mathrm{~m} / \mathrm{s}$.

\section{DISCUSSION}

About $70 \%$ of the boreholes used in this study are located on the Rima group, while the Sokoto and Gwandu formation constitutes the remaining 30\%. The studied revealed that 53 of the boreholes used for this study tap water from the Wurno while the Kalambaina and Taloka formations respectively have 7 boreholes each. Only 2 boreholes penetrate and tap water from Gwandu formation. The study showed that $54 \%$ of the boreholes which represent 37 boreholes have poor yield of less than $4 / / 5$ which ranges between $0.23-3.9$ $\mathrm{l} / \mathrm{s}$, higher yield of between 4 and 6.71/s were recorded in 30 boreholes.

Two high water yielding layers have been identified in the area, the parch water table aquifer of the Kalambaina limestone with a yield of between 0.58 to $6.7 \mathrm{l} / \mathrm{s}$ with aquifer thickness range of between $4.5-9$ $\mathrm{m}$ and a total drilled depth of between 24 to 56 metres. The second productive unit is the sandy and gravely layers of the Wurno, Taloka and Gwandu formations. A general trend was observed from the study of lithological borehole logs, for the Kalambaina limestone at shallow depth the permeability is high due to the high density and distribution of Cavernous zone, Joints/solution cavities and bedding planes which are enlarged by percolating water through solution process, hence making it possible for water to be stored and transmitted into the wells during pumping, but with greater depth this limestone becomes an aquitard. However the underlying Dange shale serves as a confirming aquiclude bed or layer at the top of the underlying Rima group.

For the Rima group and Gwandu formation, the water producing layers are the coarser sandy zone which should be thick enough to give the desire higher yield. From table 1 It will be noticed that higher yield are obtained from boreholes that has low drawdown values, thicker water bearing zones, coarse and clay free layers. It was also observed that the lower the drawdown the thicker the aquifer, and the coarser the aquifer material, the more the water stored and transmitted from the aquifer in the borehole. Also the low drawdown shows that the rate of discharge in these boreholes nearly equals the recharge which shows also that the aquifers in such locations are 
porous and highly permeable especially the limestone aquifer of the Kalambaina formation due to the presence of solution cavities that serve as conduits for the free flow or transmission of water resulting from high permeability created by the secondary opening in the limestone.

Generally, in this area of study the water producing layers are the fine, medium, Coarse Sand and Cavernous Jointed limestone layers. From the forgoing discussions the most efficient Aquifer are those with high value of Transmissivity and specific capacity, because these parameters indicate well productivity. From the result presented in (table 1), the most efficient and productive borehole in the area of study is well no 4 located at Jirga community, this has a yield of $6.7 \mathrm{l} / \mathrm{s}$, a Transmissivity of $817.40 \times 10 \mathrm{~m}^{2} / \mathrm{s}$ Specific Capacity of $670.00 \times 10 \mathrm{~m}^{2} / \mathrm{s} / \mathrm{m}$ and Hydraulic
Conductivity of $90.82 \times 10 \mathrm{~m} / \mathrm{s}$. While the least productive and less efficient borehole is well no 11 located at Gumare this has a yield of $0.28 \mathrm{l} / \mathrm{s}$, Transmissivity of $1.77 \times 10^{-2} \mathrm{~m}^{2} / \mathrm{s}$ Specific Capacity of $1.45 \times 10^{-2} \mathrm{~m}^{2} / \mathrm{s} / \mathrm{m}$ and Hydraulic Conductivity of $5.05 \times$ $10^{-3} \mathrm{~m} / \mathrm{s}$. The boreholes tapped water from the limestone aquifer and Silty sandy layers of the Kalambaina and Wurno formations respectively. Static water levels were measured after the pumping test in all the boreholes and it ranged between 5.83 and 7.48 $\mathrm{m}$.

However the shorter pumping test duration of between eight and twelve hours shows that the aquifers in the area attended equilibrium within a short period which can be attributed to Transmissivity of the aquifer material especially for the high yielding aquifer of the Kalambaina formation. 
Hamidu et al: Groundwater Resource Appraisals of Bodinga and Environs, Sokoto Basin.

TABLE 1: HYDRAULIC PROPERTIES OF BOREHOLES FROM THE STUDY AREA

\begin{tabular}{|c|c|c|c|c|c|c|c|c|c|c|c|c|c|}
\hline \multirow[t]{2}{*}{ S/No } & \multirow[t]{2}{*}{ Community } & \multicolumn{2}{|c|}{ Co-ordinates } & \multirow{2}{*}{$\begin{array}{l}\text { S.W.L } \\
(\mathrm{m})\end{array}$} & \multirow{2}{*}{$\begin{array}{l}\text { PUMPING } \\
\text { RATE(Lpm) }\end{array}$} & \multirow{2}{*}{$\begin{array}{l}\text { Yield } \\
Q(/ / s)\end{array}$} & \multirow{2}{*}{$\begin{array}{l}\text { Draw } \\
\text { Down } \\
(\mathrm{m}) \\
\end{array}$} & \multirow{2}{*}{$\begin{array}{c}\text { Aquifer } \\
\text { Thickness } \\
(\mathrm{m})\end{array}$} & \multirow{2}{*}{$\begin{array}{c}\text { Depth of } \\
\text { Borehole } \\
(\mathrm{m})\end{array}$} & \multirow{2}{*}{$\begin{array}{c}\text { Transmissivity } \\
\mathrm{T}\left(\mathrm{m}^{2} / \mathrm{s}\right)\end{array}$} & \multirow{2}{*}{$\begin{array}{l}\text { Specific } \\
\text { Capacity } \\
\left(\mathrm{m}^{2} / \mathrm{s} / \mathrm{m}\right) \\
\end{array}$} & \multirow{2}{*}{$\begin{array}{c}\text { Hydraulic } \\
\text { Conductivity K } \\
(\mathrm{m} / \mathrm{s})\end{array}$} & \multirow[t]{2}{*}{ Type of Formation } \\
\hline & & Lat. & Long & & & & & & & & & & \\
\hline 1. & Kwalfa & $12^{\circ} 56^{\prime} 11$ & $5^{\circ} 08^{\prime} 36$ & 11.86 & 26 & 6.7 & 0.08 & 7 & 24 & $102.18 \times 10^{\circ}$ & $83.75 \times 10^{\circ}$ & $14.6 \times 10^{\circ}$ & Limestone (Kalambaina) \\
\hline 2 & Kaura Tsara & $12^{\circ} 53^{\prime} 34$ & $5^{\circ} 08^{\prime} 28$ & 18.80 & 23 & 0.6 & 2.77 & 5 & 31 & $2.03 \times 10^{\circ}$ & $1.66 \times 10^{\circ}$ & $4.0 \times 10-1$ & Limestone (Kalambaina) \\
\hline 3 & Siri kaka & $12^{\circ} 53^{\prime} 55$ & $5^{\circ} 09^{\prime} 44$ & 20.27 & 23 & 0.58 & 2.49 & 4.5 & 32 & $2.84 \times 10-1$ & $2.33 \times 10-1$ & $6.32 \times 10-2$ & $\begin{array}{l}\text { Shaley } \\
\text { (Kalambaina) }\end{array}$ \\
\hline 4 & Jirga & $12^{\circ} 52^{\prime} 12$ & $5^{\circ} 08^{\prime} 39$ & 19.26 & 23 & 6.7 & 0.01 & 9 & 30 & $817.40 \times 10^{\circ}$ & $670.00 \times 10^{\circ}$ & $90.82 \times 10^{\circ}$ & Limestone (Kalambaina) \\
\hline 5 & Kaura Halya & $12^{\circ} 55^{\prime} 13$ & $5^{\circ} 09^{\prime} 28$ & 18.02 & 24 & 0.8 & 0.02 & 6.5 & 24 & $48.80 \times 10^{\circ}$ & $40.00 \times 10^{\circ}$ & $7.51 \times 10^{\circ}$ & Limestone (Kalambaina) \\
\hline 6 & Runbuki & $12^{\circ} 56^{\prime} 10$ & $5^{\circ} 07^{\prime} 9$ & 15.74 & 25 & 6.7 & 0.04 & 5 & 30 & $204.35 \times 10^{\circ}$ & $167.50 \times 10^{\circ}$ & $40.87 \times 10^{\circ}$ & Limestone (Kalambaina) \\
\hline 7 & Lukuyawa & $12^{\circ} 57^{\prime} 21$ & $5^{\circ} 06^{\prime} 50$ & 16.69 & 19 & 0.8 & 2.73 & 7 & 50 & $3.60 \times 10-1$ & $3.00 \times 10-1$ & $5.11 \times 10-2$ & Limestone (Kalambaina) \\
\hline 8 & Kwanawa & $12^{\circ} 59^{\prime} 15$ & $5^{0} 15^{\prime} 52$ & 38.05 & 15 & 4.2 & 2.17 & 2.5 & 91 & $2.36 \times 10^{\circ}$ & $2.00 \times 10^{\circ}$ & $9.45 \times 10-1$ & Coarse (Wurno) \\
\hline 9 & $\begin{array}{l}\text { Tudun Dan- } \\
\text { Dogo }\end{array}$ & $12^{\circ} 57^{\prime} 43$ & $5^{0} 17^{\prime} 3$ & 47.40 & 57 & 3.9 & 10.24 & 2.5 & 96 & $4.68 \times 10-1$ & $3.81 \times 10-1$ & $1.86 \times 10-1$ & Sand (Wurno) \\
\hline 10 & Shiyar Ajuja & $12^{\circ} 46^{\prime} 11$ & $5^{0} 15^{\prime} 5$ & 40.99 & 54 & 3.0 & 19.92 & 3.5 & 109 & $1.84 \times 10-1$ & $1.51 \times 10-1$ & $5.25 \times 10-3$ & $\begin{array}{l}\text { Medium Coarse Sand } \\
\text { (Wurno) }\end{array}$ \\
\hline 11 & Gumara & $12^{\circ} 48^{\prime} 43$ & $5^{0} 21^{\prime} 4$ & 36.87 & 7 & 0.28 & 19.33 & 2.7 & 103 & $1.77 \times 10-2$ & $1.45 \times 10-2$ & $5.05 \times 10-3$ & Silty Sand (Wurno) \\
\hline 12 & Gumara & $12^{\circ} 48^{\prime} 21$ & $5^{\circ} 20^{\prime} 44$ & 38.73 & 50 & 2.8 & 7.57 & 2.5 & 109 & $4.51 \times 10-1$ & $3.70 \times 10-2$ & $1.81 \times 10-1$ & Medium Sand (Wurno) \\
\hline 13 & Boolera & $12^{\circ} 51^{\prime} 16$ & $5^{0} 23^{\prime} 52$ & 67.88 & 23 & 1.2 & 15.43 & 2.5 & 123 & $9.50 \times 10-2$ & $7.80 \times 10-2$ & $3.80 \times 10-2$ & Dark Clayey Sand (Taloka) \\
\hline 14 & Dali & $12^{\circ} 51^{\prime} 12$ & $5^{\circ} 26^{\prime} 33$ & 20.33 & 13 & 1.6 & 4.51 & 2.5 & 72 & $4.33 \times 10-1$ & $3.55 \times 10-1$ & $1.73 \times 10-1$ & Fine Sand (Wurno) \\
\hline 15 & Majin baraya & $12^{\circ} 53^{\prime} 43$ & $5^{\circ} 23^{\prime} 40$ & 7.59 & 24 & 5.8 & 3.23 & 2.5 & 61 & $2.20 \times 10^{\circ}$ & $1.80 \times 10^{\circ}$ & $8.80 \times 10-1$ & $\begin{array}{l}\text { Clay + Medium Sand } \\
\text { (Wurno) }\end{array}$ \\
\hline 16 & Majin Baraya & $12^{\circ} 57^{\prime} 11$ & $5^{0} 23^{\prime} 51$ & 6.42 & 17 & 2.3 & 6.54 & 2.5 & 66 & $4.30 \times 10-1$ & $3.52 \times 10-1$ & $1.72 \times 10-1$ & Fine Sand (Wurno) \\
\hline 17 & Gidan Ajiya & $12^{\circ} 50^{\prime} 36$ & $5^{0} 18^{\prime} 48$ & 49.43 & 23 & 0.6 & 5.47 & 2.5 & 61 & $1.3410-1$ & $1.10 \times 10-1$ & $5.35 \times 10-2$ & Fine Sand (Wurno) \\
\hline 18 & Dankilo & $12^{\circ} 52^{\prime} 37$ & $5^{0} 18^{\prime} 22$ & 45.04 & 40 & 6.7 & 2.41 & 2.5 & 79 & $3.40 \times 10^{\circ}$ & $2.78 \times 10^{\circ}$ & $1.36 \times 10^{\circ}$ & Fine Sand (Wurno) \\
\hline 19. & Katsira & $12^{\circ} 51^{\prime} 46$ & $5^{\circ} 20^{\prime} 53$ & 50.11 & 50 & 0.9 & 10.47 & 2.5 & 67 & $1.05 \times 10-1$ & $8.60 \times 10-2$ & $4.20 \times 10-2$ & Clay+Fine sand (Wurno) \\
\hline
\end{tabular}


Nigerian Journal of Basic and Applied Science (December, 2016), 24(2): 92-101

\begin{tabular}{|c|c|c|c|c|c|c|c|c|c|c|c|c|c|}
\hline 20 & Banganange & $12^{\circ} 56^{\prime} 1$ & $5^{\circ} 20^{\prime} 57$ & 53.03 & 50 & 5.4 & 9.95 & 3.5 & 121 & $6.62 \times 10-1$ & $5.43 \times 10-1$ & $1.90 \times 10-1$ & Fine Sand (Taloka) \\
\hline 21 & Danbarunje & $12^{\circ} 57^{\prime} 5$ & $5^{\circ} 20^{\prime} 10$ & 46.54 & 54 & 2.0 & 16.56 & 2.5 & 85 & $1.47 \times 10-1$ & $1.21 \times 10-1$ & $4.21 \times 10-2$ & Fine Sand (Wurno) \\
\hline 22 & Danbarunje & $12^{\circ} 55^{\prime} 45$ & $5^{\circ} 20^{\prime} 22$ & 43.65 & 34 & 1.6 & 12.89 & 2.5 & 84 & $1.51 \times 10-1$ & $1.24 \times 10-1$ & $6.10 \times 10-2$ & Clay+Sand (Wurno) \\
\hline 23 & Battagoriba & $12^{\circ} 57^{\prime} 52$ & $5^{0} 18^{\prime} 31$ & 23.78 & 19 & 6.3 & 1.04 & 3.5 & 54 & $7.40 \times 10^{\circ}$ & $6.06 \times 10^{\circ}$ & $3.00 \times 10^{\circ}$ & Medium Sand (Wurno) \\
\hline 24 & $\begin{array}{l}\text { Dabagen } \\
\text { rikina }\end{array}$ & $12^{\circ} 58^{\prime} 41$ & $5^{\circ} 18^{\prime} 3$ & 46.14 & 57 & 5.3 & 4.59 & 2.5 & 75 & $1.41 \times 10^{\circ}$ & $1.15 \times 10^{\circ}$ & $4.03 \times 10-1$ & Fine Sand (Wurno) \\
\hline 25 & Rikina Gari & $12^{\circ} 58^{\prime} 36$ & $5^{0} 17^{\prime} 29$ & 43.74 & 56 & 5.0 & 7.55 & 2.5 & 87 & $8.08 \times 10-1$ & $6.62 \times 10-1$ & $3.23 \times 10-1$ & Very fine Sand (Wurno) \\
\hline 26 & Rikina Gari & $12^{\circ} 58^{\prime} 53$ & $5^{0} 17^{\prime} 43$ & 44.94 & 8 & 0.3 & 14.91 & 3.5 & 89 & $2.46 \times 10-2$ & $2.01 \times 10-2$ & $9.88 \times 10-3$ & Clay+Fine (Wurno) \\
\hline 27 & Birkitawa & $12^{\circ} 57^{\prime} 32$ & $5^{\circ} 24^{\prime} 36$ & 30.86 & 13 & 2.8 & 3.21 & 2.5 & 81 & $1.06 \times 10^{\circ}$ & $8.72 \times 10-1$ & $3.04 \times 10-1$ & Fine Sand (Wurno) \\
\hline 28 & Girgiri & $12^{\circ} 58^{\prime} 57$ & $5^{\circ} 23^{\prime} 0$ & 46.83 & 55 & 4.8 & 6.46 & 2.5 & 85 & $9.00 \times 10-1$ & $7.43 \times 10-1$ & $3.62 \times 10-1$ & Silty Sand (Wurno) \\
\hline 29 & Runjin Kaji & $12^{\circ} 58^{\prime} 54$ & $5^{\circ} 21^{\prime} 21$ & 15.99 & 75 & 4.9 & 6.81 & 3.5 & 54 & $8.80 \times 10-1$ & $7.20 \times 10-1$ & $3.51 \times 10-1$ & $\begin{array}{l}\text { White clay + Fine Sand } \\
\text { (Wurno) }\end{array}$ \\
\hline 30 & Dakalo & $12^{\circ} 46^{\prime} 21$ & $5^{\circ} 26^{\prime} 30$ & 60.03 & 10 & 1.3 & 1.3 & 3.5 & 89 & $1.22 \times 10^{\circ}$ & $1.00 \times 10^{\circ}$ & $3.50 \times 10-1$ & Fine silty Sand (Wurno) \\
\hline 31 & $\begin{array}{l}\text { Tudun mai } \\
\text { tandu }\end{array}$ & $12^{\circ} 59^{\prime} 34$ & $5^{0} 15^{\prime} 20$ & 41.93 & 39 & 1.06 & 5.15 & 2.5 & 79 & $2.51 \times 10-1$ & $2.06 \times 10-1$ & $7.20 \times 10-2$ & Black Sand \& Clay (Wurno) \\
\hline 32 & Jurga Rafi & $12^{\circ} 49^{\prime} 30$ & $5^{0} 18^{\prime} 52$ & 40.40 & 72 & 6.7 & 4.75 & 3.5 & 72 & $1.72 \times 10^{\circ}$ & $1.41 \times 10^{\circ}$ & $6.90 \times 10-1$ & Fine Sand (Wurno) \\
\hline 33 & Amanawa & $12^{\circ} 48^{\prime} 5$ & $5^{0} 19^{\prime} 25$ & 13.44 & 31 & 1.3 & 9.99 & 3.5 & 91 & $1.59 \times 10-1$ & $1.30 \times 10-1$ & $4.54 \times 10-2$ & Fine Sand (Wurno) \\
\hline 34 & $\begin{array}{l}\text { Tsafandi } \\
\text { Dutse }\end{array}$ & $12^{\circ} 55^{\prime} 9$ & $5^{0} 19^{\prime} 51$ & 47.8 & 27 & 0.83 & 8.61 & 2.5 & 89 & $1.18 \times 10-1$ & $9.63 \times 10-2$ & $4.70 \times 10-2$ & Fine Sand + Clay (Wurno) \\
\hline 35 & Kaura miyo & $12^{\circ} 50^{\prime} 23$ & $5^{\circ} 06^{\prime} 56$ & 41.96 & 5.5 & 0.3 & 5.78 & 2.5 & 72 & $6.33 \times 10-2$ & $5.20 \times 10-2$ & $2.52 \times 10-2$ & Sand (Wurno) \\
\hline 36 & Lugu & $12^{\circ} 55^{\prime} 12$ & $5^{\circ} 06^{\prime} 11$ & 47.30 & 13 & 6.7 & 0.34 & 4 & 100 & $24.04 \times 10^{\circ}$ & $19.71 \times 10^{\circ}$ & $6.01 \times 10^{\circ}$ & Sand+Shale (Wurno) \\
\hline 37. & Kwalafasa & $12^{\circ} 56^{\prime} 45$ & $5^{\circ} 06^{\prime} 59$ & 34.45 & 16 & 0.4 & 4.11 & 5 & 54 & $1.19 \times 10-1$ & $9.73 \times 10-2$ & $2.37 \times 10-2$ & Clay+Coarse Sand (Wurno) \\
\hline 38. & Jeba & $12^{\circ} 49^{\prime} 19$ & $5^{\circ} 05^{\prime} 16$ & 72.42 & 54 & 1.9 & 6.12 & 4 & 96 & $3.80 \times 10-1$ & $3.12 \times 10-1$ & $9.50 \times 10-2$ & Gray clay + Sand (Wurno) \\
\hline 39. & Abdulsalami & $12^{\circ} 48^{\prime} 51$ & $5^{\circ} 07^{\prime} 26$ & 24.28 & 17.5 & 0.9 & 3.56 & 4 & 96 & $3.10 \times 10-1$ & $2.53 \times 10-1$ & $7.71 \times 10-2$ & Fine Sand (Wurno) \\
\hline 40. & Mazan Gari & $12^{\circ} 50^{\prime} 52$ & $5^{\circ} 08^{\prime} 19$ & 39.90 & 44 & 2.5 & 7.87 & 3.5 & 90 & $4.00 \times 10-1$ & $3.18 \times 10-1$ & $1.12 \times 10-1$ & Fine Sand (Wurno) \\
\hline 41. & Gwarko & $12^{\circ} 51^{\prime} 6$ & $5^{0} 10^{\prime} 13$ & 48.18 & 12.5 & 0.5 & 0.47 & 7 & 54 & $1.30 \times 10$ & $1.06 \times 10$ & $1.90 \times 10$ & Coarse Sand (Wurno) \\
\hline
\end{tabular}


Hamidu et al: Groundwater Resource Appraisals of Bodinga and Environs, Sokoto Basin

\begin{tabular}{|c|c|c|c|c|c|c|c|c|c|c|c|c|c|}
\hline 42. & $\begin{array}{l}\text { Kwaciya } \\
\text { Lalle }\end{array}$ & $12^{\circ} 52^{\prime} 13$ & $5^{0} 13^{\prime} 10$ & 50.72 & 53 & 1.02 & 11.21 & 3.5 & 73 & $1.11 \times 10-1$ & $9.10 \times 10-2$ & $3.17 \times 10-2$ & Fine Sand (Wurno) \\
\hline 43. & Zanzoro & $12^{\circ} 53^{\prime} 34$ & $5^{0} 13^{\prime} 43$ & 22.03 & 21 & 6.7 & 0.22 & 2.5 & 78 & $37.20 \times 10$ & $30.50 \times 10$ & $14.90 \times 10$ & Sand (Wurno) \\
\hline 44. & Badau & $12^{\circ} 46^{\prime} 49$ & $5^{\circ} 08^{\prime} 43$ & 42.07 & 8 & 0.6 & 5.63 & 2.5 & 78 & $1.30 \times 10-1$ & $1.07 \times 10-1$ & $5.20 \times 10-2$ & Gray clay (Wurno) \\
\hline 45. & Tauma & $12^{\circ} 49^{\prime} 51$ & $5^{\circ} 09^{\prime} 34$ & 36.90 & 43 & 2.3 & 7.88 & 3.5 & 90 & $3.60 \times 10-1$ & $3.00 \times 10-1$ & $1.02 \times 10-1$ & Sand (Wurno) \\
\hline 46. & $\begin{array}{l}\text { Kaura } \\
\text { Danmalle }\end{array}$ & $12^{\circ} 47^{\prime} 41$ & $5^{\circ} 08^{\prime} 4$ & 16.84 & 23 & 6.7 & 0.32 & 3.5 & 72 & $25.54 \times 10$ & $21.00 \times 10$ & $7.30 \times 10$ & Coarse Sand (Wurno) \\
\hline 47. & Gwastu & $12^{\circ} 48^{\prime} 7$ & $5^{0} 10^{\prime} 17$ & 43.42 & 33 & 1.5 & 7.84 & 2.5 & 60 & $2,33 \times 10-1$ & $2.00 \times 10-1$ & $9.34 \times 10-2$ & Fine Sand (Gwandu) \\
\hline 48. & Karaje & $12^{\circ} 47^{\prime} 34$ & $5^{0} 13^{\prime} 16$ & 41.85 & 75 & 6.7 & 0.85 & 2.5 & 72 & $9.62 \times 10$ & $8.00 \times 10$ & $3.85 \times 10$ & Medium Sand (Gwandu) \\
\hline 49. & Shiyar Ajiya & $12^{\circ} 46^{\prime} 28$ & $5^{\circ} 014^{\prime} 32$ & 50.55 & 65 & 4 & 7.2 & 3.5 & 79 & $6.80 \times 10-1$ & $5.60 \times 10-1$ & $2.00 \times 10-1$ & Coarse Sand (Wurno) \\
\hline 50. & Karazuntu & $12^{\circ} 52^{\prime} 24$ & $5^{0} 14^{\prime} 29$ & 51.56 & 36 & 5 & 1.34 & 2.5 & 77 & $4.60 \times 10$ & $3.73 \times 10$ & $1.82 \times 10$ & Sand+Clay (Wurno) \\
\hline 51. & $\begin{array}{l}\text { Bagarune } \\
\text { danajiwe }\end{array}$ & $12^{\circ} 56^{\prime} 10$ & $5^{\circ} 10^{\prime} 30$ & 43.12 & 72 & 2.3 & 4.35 & 3.5 & 66 & $6.50 \times 10-1$ & $5.30 \times 10-1$ & $1.80 \times 10-1$ & Sand+Clay (Wurno) \\
\hline 52. & Kulodo & $12^{\circ} 58^{\prime} 37$ & $5^{0} 1158$ & 28.61 & 36 & 1.3 & 3.53 & 3.5 & 54 & $4.50 \times 10-1$ & $3.70 \times 10-1$ & $1.30 \times 10-1$ & Sand (Wurno) \\
\hline 53. & Runbu & $12^{\circ} 50^{\prime} 55$ & $5^{\circ} 08^{\prime} 16$ & 47.45 & 62 & 2.9 & 3.53 & 3.5 & 96 & $1.00 \times 10$ & $8.22 \times 10-1$ & $3.00 \times 10-1$ & $\begin{array}{l}\text { Coarse Sand with Clay } \\
\text { (Wurno) }\end{array}$ \\
\hline 54 & Chofi & $12^{\circ} 35^{\prime} 7$ & $5^{0} 14^{\prime} 41$ & 29.60 & 67 & 6.7 & 0.85 & 3.5 & 103 & $9.62 \times 10$ & $8.00 \times 10$ & $2.75 \times 10$ & Coarse Sand (Wurno) \\
\hline 55 & Kyaluje & $12^{\circ} 39^{\prime} 16$ & $5^{\circ} 19^{\prime} 44$ & 33.58 & 15 & 6.7 & 0.94 & 3.5 & 91 & $8.70 \times 10$ & $7.13 \times 10$ & $2.50 \times 10$ & Clayey sandstone (Wurno) \\
\hline 56 & $\begin{array}{l}\text { Dabagin } \\
\text { lafiya }\end{array}$ & $12^{\circ} 43^{\prime} 39$ & $5^{0} 27^{\prime} 17$ & 57.83 & 7 & 0.3 & 7.38 & 3.5 & 84 & $5.00 \times 10-1$ & $4.10 \times 10-2$ & $1.42 \times 10-2$ & Coarse Sand (Taloka) \\
\hline 57 & $\begin{array}{l}\text { Tsamiya } \\
\text { Gari }\end{array}$ & $12^{\circ} 35^{\prime} 2$ & $5^{\circ} 23^{\prime} 54$ & 11.50 & 75 & 6.7 & 1.49 & 2.5 & 40 & $5.50 \times 10$ & $4.50 \times 10$ & $2.20 \times 10$ & Coarse Sand (Taloka) \\
\hline 58 & Tsamiya & $12^{\circ} 35^{\prime} 4$ & $5^{0} 23^{\prime} 56$ & 5.83 & 75 & 6.7 & 2.47 & 2.5 & 33 & $3.31 \times 10$ & $2.7 \times 10$ & $1.32 \times 10$ & Coarse Sand(Taloka) \\
\hline 59. & Bangi & $12^{\circ} 44^{\prime} 5$ & $5^{0} 16^{\prime} 0$ & 74.15 & 9 & 0.53 & 1.82 & 3.5 & 91 & $3.60 \times 10-1$ & $3.00 \times 10-1$ & $1.02 \times 10-1$ & Fine Sand(Wurno) \\
\hline 60. & Bangi & $12^{\circ} 44^{\prime} 6$ & $5^{0} 15^{\prime} 42$ & 44.48 & 9 & 0.23 & 2.78 & 3.5 & 90 & $1.01 \times 10-1$ & $8.30 \times 10-2$ & $3.00 \times 10-2$ & Fine + clay(Wurno) \\
\hline 61. & Dandin Make & $12^{\circ} 43^{\prime} 22$ & $5^{\circ} 07^{\prime} 8$ & 48.2 & 47 & 6.7 & 0.8 & 3.5 & 91 & $10.22 \times 10$ & $8.40 \times 10$ & $3.00 \times 10$ & $\begin{array}{l}\text { Fine Sand } \\
\text { clay(Wurno) }\end{array}$ \\
\hline 62. & Kwamtsi & $12^{\circ} 41^{\prime} 51$ & $5^{0} 10^{\prime} 52$ & 49.5 & 39 & 5.1 & 6 & 3.5 & 121 & $1.04 \times 10-1$ & $8.50 \times 10-1$ & $3.00 \times 10-1$ & Black fine Sand(Wurno) \\
\hline
\end{tabular}


Nigerian Journal of Basic and Applied Science (December, 2016), 24(2): 92-101

\begin{tabular}{|c|c|c|c|c|c|c|c|c|c|c|c|c|c|}
\hline 63. & Lugge & $12^{\circ} 43^{\prime} 41$ & $5^{0} 11^{\prime} 59$ & 26.1 & 68 & 6.7 & 2.9 & 2.5 & 91 & $2.82 \times 10$ & $2.31 \times 10$ & $1.13 \times 10$ & Coarse to fine Sand (Wurno) \\
\hline 64. & $\begin{array}{l}\text { Kwantsi } \\
\text { Danchadi }\end{array}$ & $12^{\circ} 45^{\prime} 1$ & $5^{\circ} 08^{\prime} 0$ & 49.4 & 26 & 1.08 & 23.7 & 2.5 & 138.5 & $5.60 \times 10-2$ & $4.00 \times 10-2$ & $2.22 \times 10-2$ & Fine sand(Wurno) \\
\hline 65. & $\begin{array}{l}\text { Kwantsi } \\
\text { Danchadi }\end{array}$ & $12^{\circ} 43^{\prime} 49$ & $5^{0} 13^{\prime} 50$ & 23.4 & 72 & 6.7 & 5.3 & 2.5 & 88 & $1.26 \times 10$ & $1.54 \times 10$ & $6.17 \times 10-1$ & Fine Sand with clay (Wurno) \\
\hline 66. & Siri Modi & $12^{\circ} 44^{\prime} 55$ & $5^{\circ} 08^{\prime} 20$ & 33.4 & 77 & 6.7 & 1.7 & 3.5 & 72.5 & 4.81 & $4.00 \times 10$ & $1.37 \times 10$ & Fine Sand(Taloka) \\
\hline 67. & Da Kalo & $12^{\circ} 44^{\prime} 36$ & $5^{0} 12^{\prime} 45$ & 32.5 & 54 & 6.7 & 5.5 & 2.5 & 103 & 1.50 & $1.22 \times 10$ & $6.00 \times 10-1$ & Fine Sand(Wurno) \\
\hline
\end{tabular}




\section{CONCLUSION}

The Bodinga area and environs has abundant groundwater resources with higher yield mostly occurring in the thicker Sandy layers and solution openings in the limestone units. Generally the water comes from the Kalambaina, Wurno, Taloka, and Gwandu formations. The clayey layers of these formations are thicker than the sandy units with depth increase; the presence of these finer clayey and Silty materials within the Aquiferous layers reduces the performance and efficiency of this unit as water storing and producing unit. However, this can be improved through longer duration of pumping, proper well development and construction.

\section{REFERENCES}

Adelana S. M. A., Olasenhinde P. I and Vrbka P. (2006) Quantitative Estimation of groundwater Recharge in part of the Sokoto Basin Nigeria, Journal of Environmental Hydrology, 14(5): 116.

Anderson H.R. and Ogilbee W. (1973) Aquifers in the Sokoto Basin, Northwestern Nigeria, with a description of the general Hydrogeology of the region. Geological Survey water supply paper 1757. Published by the U.S. Agency for international development. p88

Alagbe S. A. (2004). Hydrogeology of the Kalambaina Limestone Aquifer, Sokoto basin Northwestern Nigeria. Unpublished PhD thesis department of Geology Ahmadu Bello University Zaria p188.

Dupreez J. W. and Barber. W. (1965). The distribution and quality of groundwater in northern Nigeria. Nigeria Geol. Survey Bull 36 : 38-45.

Guillaume F., Yahaya N., Marc L. , Abdou G. and Ibrahim B. G. (2011). Groundwater resources increase in the lullummeden Basin, West Africa. 113-128.

Hamidu H., Abdullahi I.M, Nura N.A., Falalu B. H., Mohammed .D, (2015). Comparative study of groundwater resources in the basement complex and sedimentary terrain of Talata mafara town and environs Zanfara state. Pelagia Research library journal of advances in Applied Science Research, 6(1):27-33.

Japan international co-orperation Agency (JICA) (1990) . The study for groundwater developmet in Sokoto state. 2. Main report.

Jones, B. (1948). The sedimentary rocks of Sokoto province, Nigeria Geol. Survey bull.18, p75

Kogbe C. A. (1979). Geology of the Eastern Sokoto sector of the lullummeden Basin. Bull Department of Geology Ahmadu Bello University Zaria, Nigeria, 2(1)::420p

Maduabuchi C. M. (2002). Case studies on Transboundary Aquifers Nigeria, Proceedings of the international workshop Tripoli, Libya pp. 137-141.

Oteze, G. E. (1976). The Hydrogeology of Northwestern Nigerian Basin, in Geology of Nigeria. Edited by Kogbe G. An Elizabeth press. Pub.

Oteze, G.E. (1989), Recharge characteristics of Rima Aquifer, Sokoto Basin. Water resources, 1,154160.

Paker D. H. (1964) Geological map of Nigeria. Nigerian Geol. Survey series; 250,000 sheet nos 1, 2, 3, 7 and 8.

Umar, I. U (2000). An outline of the hydrogeology of the Sokoto - Rima Basin in Nigeria. Paper presented at the first National Workshop on application of Isotopes Techniques in water resources Development and Management held in Sokoto, Nigeria.

Wardrop Engineering Consultant (1985). Final Completion report on the drilled 1406 hand pump equipped boreholes for SARDA. 